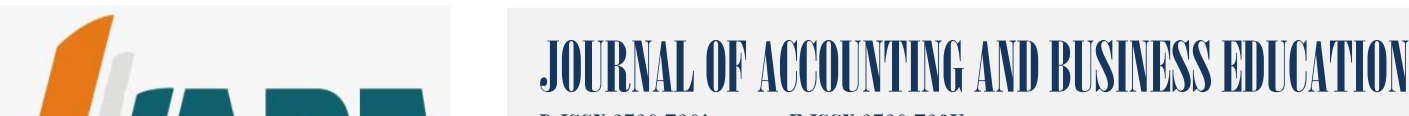 \\ P-.SSI 2928-7281 R-ISSI 2528-729X

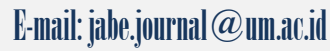

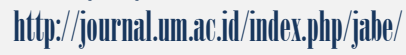

\section{The Effect of Budget Participation to Budgetary Slack With External Pressure as Moderating Variable}

\author{
Robith Abdullah Rifqi \\ Imam Subekti \\ Aulia Fuad Rahman \\ Universitas Brawijaya \\ aarobith@gmail.com
}

\begin{abstract}
This study aims to examine empirically the effect of budget participation on budgetary slack and the influence of external pressure as a moderating of the relationship between budget participation and budgetary slack in Probolinggo Municipal Government. The sample was 105 employees participated in the budgeting process at 40 Local Government Units (LGU) in Probolinggo Municipal Government. This study was using multiple linear regression. The outcomes indicated that the greater level of employee participation in the preparation of the budget, the budgetary slack will be reduced. Unfortunately, this study was not able to prove that the interaction between budget participation and external pressure strengthen the relationship between budget participation and budgetary slack. Yet, external pressure can reduce budgetary slack.
\end{abstract}

Keywords: budget participation, budgetary slack, external pressure.

\section{INTRODUCTION}

Budgeting expects organizations to make an interpretation the overall strategy into short and long haul objective designs (Hansen and Mowen, 2006). Budget preparation is very influential on the success of the implementation of programs and activities in the future. Budgets are the consequence of arrangements between organization objectives and worker objectives. The arrangement of corporate targets with the point of employees (goal congruence) is ideal and sought after by the organization in the readiness of the financial plan.

Budget preparation is likewise done by public organizations, for instance, local governments, in this case, is done by the Local Government Unit (LGU). The process of budgeting in LGU is an important activity and involves various parties ranging from LGU head 
to staff. For the government, a budget is a political contract between the government and the House of Representative (Mardiasmo, 2002).

Budgeting within the local government has entangled stages and even high political subtleties. Dissimilar to the private sector, the budget is the company's secret. Public sector budgets ought to be informed for discussion and input. The public sector budget is an instrument of accountability for the management of public funds and the implementation of programs financed by taxpayers money.

Head of LGU tends to determine revenue focuses beneath the actual potential, bringing about the contrast between the actual revenue potential with the target revenue proposed by the head of LGU. On the other hand, when budgeting expenditure, LGU heads incline toward spending sums above genuine needs. Head of LGU leans towards a larger budget allocation of real costs when budgeting. The distinction between actual needs and budgetary spending is the budgetary slack within the budget (Abdullah, 2012).

Decisions in budgeting are influenced by many factors, including economics, politics and technology, however the impacts of those are not known until genuinely figured it out (Forrester, 1991). Pursuant to the data of SIMDA Finance of Probolinggo City since the fiscal year 2013 until the fiscal year 2015 there is a considerable budget remaining. Expenditure budget is raised above requirement, actual expenditure.

Table 1. Actual Expenditure of Probolinggo Municipal Government

\begin{tabular}{|lccrrr}
\hline No & Year & Budget (Rp.) & Actual Expenditure (Rp.) & \% & Remaining Budget (Rp) \\
\hline $\mathbf{1}$ & 2013 & $732.492 .777 .762,65$ & $655.932 .038 .459,43$ & 89,55 & $76.560 .739 .303,22$ \\
\hline $\mathbf{2}$ & 2014 & $907.766 .807 .435,83$ & $778.254 .103 .607,97$ & 85,73 & $129.512 .703 .827,86$ \\
\hline $\mathbf{3}$ & 2015 & $894.026 .082 .490,62$ & $690.251 .408 .482,08$ & 77,21 & $203.774 .674 .008,54$ \\
\hline
\end{tabular}

Numerous prior studies connected subordinate participation in budgeting to budgetary slack. Prior studies have demonstrated that budgeting slack happens on account of the inclination of data gave by subordinates to chief by announcing bigger expenses or lower pay targets (Young, 1985) and (Merchant, 1985). Research led by Young (1985) and Merchant (1985) demonstrates that subordinates desire to maintain a strategic distance from chance in budgeting arrangement, along these lines making budgeting slack. 


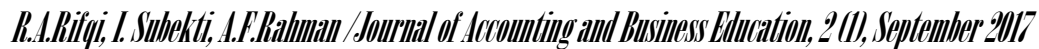

Several prior studies have demonstrated diverse research outcomes. The more participating in budgeting the more probable the budget slack (Schiff and Lewin, 1970; Lukka, 1988; Young, 1985). Be that as it may, different analysts assert that the more participating in budgeting, the more outlandish the budget slack (Merchant, 1985)

The distinction between the prior research on the participation of the budget with the budget slack caused by the presence of specific factors that situational factors or known as contingency variables (Govindarajan, 1986). This examination, then, utilized moderation variables external pressure that allegedly can fortify the connection between budget participation with the budget slack.

Unlike the private sector that obtains funds from the offer of products or services, the local or municipal government derives reserves from taxes paid by the public. In this way, the private sector is all the more allowed to deal with its finances, while local governments should pay attention to external parties such as communities, NGOs, mass media or legislatures.

The utilization of outer weights as directing factors that fortify the relationship of budgeting participation and budgeting slack depends on several notions: (1) Public Organozations can not be isolated from outer weights, for instance, the impact of political associations (Julnes and Holzer, 2001) (2) Outer weight emerges as long as correspondence exists with outer stakeholders, authoritative and group (Wang, 2002).

Beginning from the background of the above-mentioned issues, this study is to test observationally the influence of budgetary participation on the budget slack. And additionally to test empirically the influence of outer weights in moderating the effect of budgetary participation on the budgetary slack.

\section{LITERATURE REVIEW AND HYPOTHESES}

\section{Contingency Theory}

Contingency theory expresses that the effectiveness of the design of a management accounting system relies upon the combination of the organization and its environment. Otley's (1980) thought demonstrates that the achievement of organizational management does not depend entirely on management's motivation and means of management, yet additionally by an environment completely outside the organization's control. Research in the field of management accounting aims at taking the relationship between the contextual variables with the design of the 


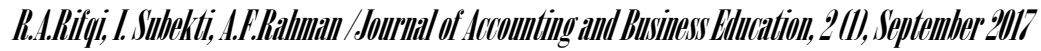

management accounting system and to evaluate the viability of the relationship between two variables, for instance, the relationship between budget participation with budgetary slack by utilizing contextual variables as moderating variables. The moderating variable in this study is outer weights.

The challenge for most important service organizations is addressing unique attributes that can prompt troubles in quality control, performance measurement and cost control (Auzair, 2010). Mature mass service companies place a more bureaucratic accentuation on management

control systems than professional service firms. Hence, it underpins generalizations to public service organizations from different ventures in light of comparable characteristics of their service processes.

While there is contrast between service firms and manufacturing companies, however profit-making service firms have similarities with manufacturing firms in accentuating profitability objectives and meeting performance targets (Auzair and Smith, 2004). Some literature recommends that management control systems are equally important in service organizations. The service management system of the service organization ought to be considered in a more extensive setting, which incorporates accounting for external and internal unforeseen variables. Along these lines, contingency theory appropriates to the manufacturing sector may likewise apply to the public sector.

\section{Budgetary Slack}

Budgeting slack is a deliberate undertaking by managers in charge of for budgeting by presenting budget proposals and estimates that are inconsistent with genuine potential, bringing down the revenue that can be generated and raising the required costs (Dunk, 1993). The budgeting slack is done as a manager's effort to approach the safe limit in achieving the organization's target budget.

The budgeting slack in the LGU occurs when the set budget far surpasses the actual spending potential. This happens on the grounds that the budget allocation using the maximum base, i.e the amount of budget is the benchmark of the maximum amount of payments that can be realized. Subsequently, the budget slack demonstrates the distinction between the actual amount of spending expenditure and the budgeted one. 


\section{Budget Participation}

Budget is part of management control system that serves as an instrument of planning and control with the objectives that managers can implement activities and programs of the organization viably and efficiently (Schief and Lewin, 1970). Imperative elements of service firms pertinent to the design of management control systems are the participation of people (Auzair and Smith, 2004). Likewise, Auzair and Smith additionally express the exceptional attributes of an unadulterated service organization including (1) intangible services, (2) unspecified production from consumption, where customers are likewise engaged in the production of services, (3) the rapid deterioration of services, Unused will be lost, and (4) heterogeneity in service products, where the services provided by the same person may differ between customers or specific time.

Participation in the organization's budget is the procedure by involving managers in defining budget goals under his or her responsibility (Brownell, 1982). Participation manager in the preparation of the budget, will add information to superiors regarding the environment and encourage solving problems related to the budget. Participation can likewise reduce uneasiness in subordinates as they can discover relevant, acceptable and accessible goals. Participation in budgeting is an effective way of creating goal alignment.

\section{Outer Weights}

The relationship between outer weights and budgetary slack in terms of institutional theory is due to coercive isomorphism. Coercive isomorphism is the after effect of formal and informal weights provided by the organization to other organizations that rely upon the expectations of the community in which the organization operates (DiMaggio and Powell, 1983).

To better comprehend coercive isomorphism, researchers initially convey institutional theory. Institutional theory is based on the idea that to survive, the organization must convince the public that the organization is a legitimate entity and deserves support (Meyer and Rowan, 1977). This theory is utilized to depict actions and decision-making in public organizations (Scott, 2008). Institutional theory emerges as an explanation for individual and organizational actions caused by external factors (Frumkin and Galaskiewcz, 2004), exogenous factors (Dacin, 1997), societal expectations (Ashworth, et al., 2009), environmental factors (Jun and Weare, 2010). 
Organizations that prioritize legitimacy will have a tendency to adjust to the external expectations or social expectations that the organization is in (DiMaggio and Powell, 1983). Adaptation to external expectations or social expectations prompts the emergence of an organizational tendency to separate internal activities and put more accentuation on systems that are representative of external parties (Meyer and Rowan, 1977).

Public sector organizations, for instance, local governments are straightforwardly reliant on central government funds with reserves from the community, thereby reacting to policy changes and pressure to improve public services (DiMaggio and Powell, 1983). Public organizations, in this case the local government, indirectly rely on broader public opinion to manufacture a decent impression and legitimacy of the central government which is beneficial to the local government.

\section{LITERATURE REVIEW AND HYPOTHESES}

The budgeting slack is a deliberate undertaking by managers by presenting budget recommendations and estimates that do not fit the genuine potential, by bringing down the revenue that can be generated and raising the required costs (Dunk, 1993). This is done to make it simpler to accomplish the objective budget set by the company.

The inclination to make budgetary slack diminishes when managers partake actively in budgeting (Merchant, 1985). This happens due to positive correspondence and information exchange between managers with the goal that subordinates feel less pressure. With diminished pressure perceived by subordinates in achieving corporate targets, then it reduces the inclination of the occurrence of budget disparities. Similarly in the public sector, some researchers contend that budgetary participation can diminish the occurrence of budgetary slack, (Rahim, 2013; Rahmiati, 2013).

Findings that demonstrate the contrast between one study and another indication that there might be different variables influencing the relationship between budgetary participation and the budgeting slack. The absence of unity within the outcomes of the prior research with respect to the budget and its implications is due to certain factors (situational factors) or better known as contingency variables (Ghozali, 2006). The difference in the results of the study can be settled through a contingent approach (Govindarajan, 1986). This is done by including different variables that might affect participation with the budgeting slack.

Public organizations can not be separated from outer weights, for instance, the influence of political organizations (Julnes and Holzer, 2001) and in addition in the preparation of budgets 
to local governments can not be separated from outer weights, for instance, legislative, mass media and society. Outer weight emerges as long as communication exists with external stakeholders, legislative and community (Wang, 2002).

An official budget compilers know how much potential income and expenditure of LGU which they can determine the amount of budget that is easily reached. Meanwhile, from outside the organization, for example, individual just propose activities through musrenbang, the mass media can only convey the facts and opinions of a budget, and the legislature can set a budget or refuse the budget. In any case, external parties are unconscious of the genuine budget potential, hence each LGU officials take a role in determining the specific amount of local budgeting. In view of the above description of outer weights is a moderator that fortifies the relationship between budgetary participation and budgetary slack, the conceptual framework is put forward below.

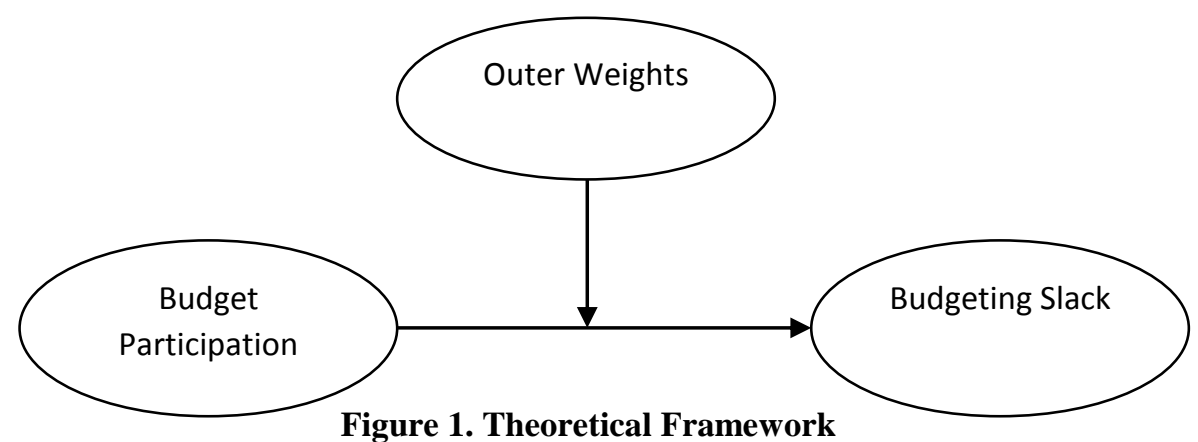

\section{Budget Participation and Budgeting Slack}

Budget participation is defined as a procedure where budgeting planners involve and possess influence on determining budgeting allocation (Anthony dan Govindaradjan, 2005). Budget participation, practically, can diminish budgeting slack since within the budget participation positive correspondence among the managers occurs. Further, this positive correspondence will diminish subordinate's pressure and weight to accomplish organization target and diminish the tendency of a subordinate in experiencing budgeting slack (Merchant, 1985). In addition, the more budget participation from subordinate the more probable information required enhancement will occur and eventually it improve the accuracy of budgeting. Budgetary participation encourages harmony, ownership and responsibility towards organizational goals by participating in budgeting (Milani, 1975). Earnestness in accomplishing 
organizational goals by subordinates will increase the effectiveness of the organization, thus reducing the tendency of managers to make budgetary slack.

Budgetary participation is believed reducing the occurrence of budgetary slack if subordinates provide personal information regarding the future prospects of the organization hence the budget is designed to be more accurate. Budget participation demonstrates the extent of participation of local government officials in understanding the budget proposed by each LGU. Several public sector studies have suggested that budgetary participation negatively affects budgeting slack (Rahim, 2013; Rahmiati, 2013). More taking an interest in budgeting will reduce the tendency of managers to make budgetary slack.

Budget participation increases employee motivation and commitment to the budget, encourages creativity among all levels of employees, enhances the sense of responsibility and participatory budgeting which helps to ensure more accurate and reliable estimates (Othman and Haryanti, 2012). Through participatory budgeting, employees can provide and obtain more relevant information to set budget goals. Budgetary participation also provides feedback to higher-ranked management to improve the budget process (Othman and Haryanti, 2012) therefore more budgetary participation is expected to reduce the budget gap.

One of the objectives of the budgeting slack made by officials in the private sector is to avoid risk (Young, 1985). Risks emerge because of future uncertainty. The greater the uncertainty, the greater the risk faced by the company. Profit-oriented companies are more susceptible to uncertainty in the future than public sector organizations (Auzair and Smith, 2004). The uncertainty of the future of local government is much lower than that of the private sector thus the risks faced by local governments are also lower than the private sector. Therefore, budget gaps in local governments are not as large in the private sector as the risk of confronting future uncertainty.

Subordinates feel their performance will be evaluated according to the level of budget achievement, accordingly to encourage the accomplishment of budgets, subordinates do not give all the information to the authority during the preparation of the budget (Dunk, 1993). In order to effortlessly accomplish budget targets, subordinates perform budgetary slack. With the achievement of the budgetary targets, subordinates will earn a reward. On the other hand, if the subordinates fail to do so, they will be warned and attain an allowance cutting. 
Local governments undertake an assessment of performance in light of budgeting accomplishment, however, either accomplished or not, budgeting targets did not influence profession or wage of an authority or official. Regardless they obtain benefits, no conclusion of advantages and no punishments imposes for not achieving the budgeting targets. Additionally, if the budgeting targets of LGU achieved, no reward for the head of LGU and authorities in local government. The absence of accentuation on performance appraisal in local government makes the accomplishment of budgeting targets less than the maximum. Since the strain to accomplish the financial backing is not as substantial as in the private area, budgetary participation in local government does not expand the budgetary slack but rather diminishes the budgetary slack.

The distinction between private sector and local government in accomplishing budgeting target and performance, in addition to reward and punishment absence, it deals with the different capital owned. Within the budgeting of private sector, the capital is attained from corporate ownership or corporate investors. Meanwhile, local government attains its capital from central government budgeting distribution and predominantly from taxpayers money. Managerial officials are conscious upon their basic income is influenced by capital transferred by the owner of corporate. Manager as official management of corporate believes that the better corporate performance the greater their income. On the other hand, in the local government context, official LGU income is not influenced by the authority. Wages system of government officials or civil servants has been established by the central government pursuant to the rank or classification of official as well as work period of the official. Subsequently, the authority does not possess a capacity to cut or add subordinates' income which at the end, reliance and expectation on authority in local government are less significant than in private sector, for instance corporation.

The less noteworthy reliance and expectation of subordinates to the authority are likewise compelling in the readiness of the budget arrangement. Subordinates who partake in the preparation of the budget turned out to be more autonomous. The possibility of a more autonomous individual is more genuine than the one under weight. Henceforth, the financial backing arranged under these genuine conditions will diminish the budgetary slack.

Some prior research results in local governments concerning on budget participation negatively affect the budget gap are discovered by Rahim (2013), Rahmiati (2013) and Syahrir (2016). In accordance with the above-mentioned assertion, the researchers of this present study 


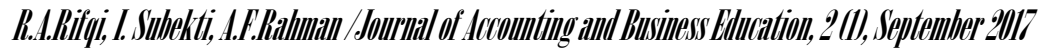

account that participation within budget arrangement negatively influences on the budgetary slack, meaning that budget participation substantially diminishes budgetary slack.

H1: Budget participation negatively affects budgetary slack.

\section{Budget Participation, Outer Weights, and Budgetary Slack}

Coercive isomorphism is the after effect of both formal and informal outer weights provided by other organization in which the organization depends (DiMaggio and Powell, 1983). In dealing with the government, the local government relies on taxes with funds derived from the community, in this way the local government can not be isolated from the impact of society, particularly those sitting in the legislature.

Coercive isomorphism originates from political impact and legitimacy needs (DiMaggio and Powel, 1983). Essentially in the public sector, budgeting in local government is indistinguishable from the political impact. Beginning from the preparation of the general budget policy and the provision of the temporary budget ceiling (KUA-PPAS) until the assurance of the provincial budget dependably includes the House of Representatives.

The regulation objective is to govern organization to establish a decent circumstance. The coercive power of a rule causes the organization has a tendency to obtain or enhance its legitimacy (Scott, 1987), so as to emphasize only the positive aspects (Hess, 2007) to expose a positive depiction of an organization for external parties. In order for the local government to be well regarded by the community (external parties), the local government tends to comply with the prevailing regulations.

The results of Cavalluzzo and Ittner (2004) and Akbar et al. (2013) states that systems used to address external needs tend to influence organizational behavior more prominent than to meet the internal needs of the organization. They additionally contend that organizational legitimacy increases in proportion to external expectations of the accuracy of the management control system to be more modern, rational and efficient, yet this tends to make internal organizational activity is negligible emblematic and more centered around external parties. Outer weights can increase the legitimacy and effectiveness of the organization (Wijaya and Akbar, 2013). With the increased legitimacy and effectiveness, the organization is expected to increase also effectiveness in preparing the budget. Alongside the increased effectiveness in budget preparation, it is expected to reduce the budgetary slack. 
External weights are the power from outside the association that cutoff points organizational strides in performing errands (Frumkin and Galaskiewicz, 2004). An instance of outer weights in budget preparation incorporate community involvement in musrenbang, the part of the House of Representative in the local budgeting procedure, the mass media that has the ability to shape general sentiment, and in addition directions or laws that must be clung to.

Budgeting consists of four stages: executive planning, legislative approval, executive implementation, and ex-post accountability (Von Hagen, 2002). The interaction between the executive and legislative occur in first and second stages. The executive will feel the weight in this procedure due to the numerous political interests of the governing body.

DiMaggio and Powell (1983) found that lower-level organizations were made a request to take after practices and structures as per the organization's parent policy. Local governments must take after controls set by the central government. In the financial matters of local government ought to be liable to central government regulations. For instance, Regulation of the Minister of Home Affairs Number 21 of 2011 on the Second Amendment to the Regulation of the Minister of Home Affairs Number 13 of 2006 concerning Guidelines on Regional Financial Management.

As mentioned in the literature review, organizations favoring legitimacy tend to adapt to the external expectations or social desires that the organization is in (DiMaggio and Powell, 1983). The city mayor as the regional head is a political authority elected directly by the people. This means that a regional head needs community bolster, consequently the head of the region is probably going to meet the expectations of the community.

The initial step towards understanding the desires of society is through the arrangement of a budget that stands for the community. Henceforth the public expectations (external parties) incorporated into the budget and spending of local government (APBD). An authority taking an interest in budgeting will be under strain to oblige the desires of the community. The number of external parties who are keen on the preparation of the budget to make subordinates more cautious in deciding the sum or cost of an action. Hence, it is normal that the collaboration between budget participation and outer weight is relied upon to diminish the budgetary slack.

In accordance with the aforementioned theory and assertion, it is assumed that external pressure can fortify the negative effect of budgetary participation on budgetary slack. With moderation of outer weights budget participation will further diminish the budgetary slack. 
H2: The negative effect of budgetary participation on the budgetary slack will be fortified when there are outer weights.

\section{METHODS}

This sort of research as a part of this investigation is hypothesis testing utilizing the descriptive approach. Descriptive approach is a research to portray the impact of independent variables on the dependent variable (Hartono, 2007). This study utilized a quantitative approach, since it depicts the relationship between research variables through hypothesis testing and data presented in the form of numbers calculated through statistical tests.

The population used as a part of this investigation is LGU in Probolinggo Municipal Government. The unit of analysis in this study is the officials involved in the preparation of budgets ranging from Head of LGU, Technical Executing Officer (PPTK) to Sub-Division Head of program compilers. The samples in this study using purposive sampling method with judgment sampling. It implies that researchers have certain contemplation in choosing the sample. The selected sample is limited to the people involved in preparing the budget so it is relied upon to provide information according to the actual situation in the field.

In accordance with the Minister of Home Affairs Regulation No. 21 of 2011 on the Second Amendment to the Regulation of the Minister of Home Affairs Number 13 of 2006, the task of preparing Workplan Budget and LGU Budget Execution Document is in the hands of the Head of LGU as the power of the budget user. During the implementation, head of LGU establishes a budget compilation team to arrange LGU Workplan Budget. Pursuant to the Decree issued by the Head of LGU, it can be seen that the officials involved in the preparation of the budget are the secretary or administration and Technical Executing Officer (PPTK). This study employed three groups of respondents in each LGU namely Head of LGU, Secretary or administrative affairs official and Technical Executing Officer (PPTK). The selection of these three groups of respondents has represented structural levels of officials ranging from echelon II to echelon IV officials. The total number of respondents is 120 people, each LGU consists of 3 people.

The sort of data utilized is the primary data, i.e data obtained directly from the original source. Primary data were collected by the researcher to answer the research question.

Data collection in this study was utilizing a questionnaire that is, an arrangement of inquiries that are set up to be submitted to the respondent. This questionnaire contains a rundown 
of structured questions addressed to respondents with a view to obtaining written information relating to budgetary participation, outer weights and LGU budgetary slack.

This research model derives from three equations to calculate the coefficient in testing the direct effect and moderation effects of the research model, the following is the equation:

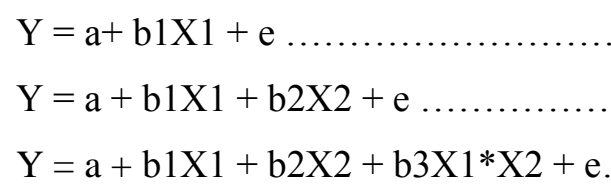

Remarks:

$\mathrm{Y} \quad=$ budgetary slack variable

a $\quad=$ constant

b1 = regression coefficient budget participation

b2 = coefficient of regression outer weights

b3 = interaction variable coefficient of budget participation and outer weights

$\mathrm{X} 1=$ variable budget participation

$\mathrm{X} 2=$ variable outer weights

$\mathrm{X} 1 * \mathrm{X} 2=$ variable interaction of budget participation and outer weights

$\mathrm{e} \quad=$ residual value

This study tested the hypothesis proposed using SPSS assistance. Hypothesis 1 was tested by simple regression, while hypothesis 2 using multiple regression. The initial step of regression is done to see the immediate influence of the independent variable to the dependent variable. The second step of the regression is done to include the moderation variable. The third step is to enter the interaction between the moderation variable and the independent variable.

\section{RESULTS}

\section{Validity Testing using Factor Analysis and Reliability Testing}

The research instrument testing was conducted to determine the validity and reliability of research instruments before being utilized for genuine data collection. Instruments used further in the study must meet the valid and reliable criteria, in light of the results of validity and reliability tests that have been done.

The validity of the questionnaire items is known to perform a confirmatory factor analysis and consider the value of the Emperor-Meyer-Olkin Measure of Sampling (KMO MSA), Anti-Image, and Rotation Component Matrix. The first assumption that must be satisfied by confirmatory factor analysis is that matrix data must have sufficient correlation (Ghozali, 2006) that the MSA KMO value must be more than 0.50. and significance (sig.) of Bartlett is below 0.05 . The next thing to note is Anti Image Matrices Table, where the value Measure of 
Sampling Adequacy (MSA) must be greater than 0.5. If there is less than 0.5, then the indicator must be removed. If there is more than one variable that has an MSA below 0.5 then the variable is removed with the smallest MSA and the testing process is repeated until the entire MSAs are above 0.5 .

Table 2. KMO MSA and Bartlett's Test

\begin{tabular}{ccc}
\hline Remarks & $\begin{array}{c}\text { Kaiser-Meyer-Olkin } \\
\text { MSA }\end{array}$ & Sig. Bartlett's \\
\hline Independent Variable & 0,720 & 0,000 \\
Dependen Variable & 0,710 & 0,000 \\
\hline
\end{tabular}

If KMO MSA has been fulfilled for factor analysis, the next step is to see the value of MSA in Anti Image Table. The value of MSA in each indicator can be seen in the table as follows:

According to the Anti Image Table of Independent Variables below, it is known that MSA of the entire indicators is greater than 0.5. Similarly, the value of MSA Dependent Variables which is presented in Anti Image Table. This shows that the entire indicators used to measure budget participation and outer weights are valid.

Table 3. Anti Image of Independent Variable

\begin{tabular}{|c|c|c|}
\hline \multicolumn{2}{|c|}{ Item } & Anti image \\
\hline PA_1 & $0,868^{\mathrm{a}}$ & \\
\hline PA_2 & $0,772^{\mathrm{a}}$ & \\
\hline PA_3 & $0,805^{\mathrm{a}}$ & \\
\hline $\mathrm{PA}_{-4}^{-4}$ & $0,775^{\mathrm{a}}$ & \\
\hline $\mathbf{P A}_{-}^{-} 5$ & $0,818^{\mathrm{a}}$ & \\
\hline PA_6R & $0,835^{\mathrm{a}}$ & \\
\hline TE_1 & $0,551^{\mathrm{a}}$ & \\
\hline TE_2 & $0,727^{\mathrm{a}}$ & \\
\hline $\mathrm{TE}_{-}^{-} 3$ & $0,642^{\mathrm{a}}$ & \\
\hline TE_4 & $0,588^{\mathrm{a}}$ & \\
\hline TE_5 & $0,548^{\mathrm{a}}$ & \\
\hline TE_6 & $0,582^{\mathrm{a}}$ & \\
\hline TE_7 & $0,684^{\mathrm{a}}$ & \\
\hline TE_-8 & $0,627^{\mathrm{a}}$ & \\
\hline TE_9 & $0,622^{\mathrm{a}}$ & \\
\hline
\end{tabular}

Table 4. Anti Image of Dependent Variabel

\begin{tabular}{cc}
\hline Item & $\begin{array}{c}\text { Anti } \\
\text { image }\end{array}$ \\
\hline KA_1 & $0,691^{\mathrm{a}}$ \\
\hline KA_2 & $0,709^{\mathrm{a}}$ \\
\hline KA_3 & $0,792^{\mathrm{a}}$ \\
\hline KA_4 & $0,662^{\mathrm{a}}$ \\
\hline
\end{tabular}




\begin{tabular}{ll}
\hline KA_5 & $0,780^{\mathrm{a}}$ \\
KA_6 & $0,609^{\mathrm{a}}$ \\
KA_7 & $0,581^{\mathrm{a}}$ \\
\hline
\end{tabular}

One important instrument for interpreting KMO MSA factor analysis and the anti image is a factor rotation. PA_1 to PA_6R indicator clustered at factor 1, indicator TE_1 to TE_5 clumped on component 2 however TE_6 to TE_9 indicators are in component 1. Therefore, TE_6 and TE_9 indicators must be removed one by one in order to make the construct does not have unidimensionality. The te_9 indicator is issued first and at that point seen again whether there is still an outer weights indicator in group one. If it is continued to exist then, it must be reissued until there is no outer weights indicator in component one. As for KA1 to KA7 indicator is not formed the rotation of the component because there is only one component only.

After the data obtained is confirmed valid, then it is continued with the reliability test. The instrument has a high reliability if the coefficient is obtained greater than 0.60 (Ghozali, 2006). Below is a summary of reliability test results:

Table 5. Summary of Reliability Test Results

\begin{tabular}{ll}
\hline \multicolumn{1}{c}{ Variable } & $\begin{array}{l}\text { Cronbach } \\
\text { Alpha }\end{array}$ \\
\hline Budgetary Slack & 0,722 \\
Budgeting Participation & 0,827 \\
Outer Weights & 0,732 \\
\hline
\end{tabular}

As indicated by the test outcomes, it was realized that Cronbach alpha values of the entire variable are greater than 0.60 . Therefore, it is concluded that this research instrument is reliable. Reliable instruments can provide consistent results when re-done with the same subject. The following stage subsequent to the validity and reliability, it proceeded with regression test. The researchers summarize the findings in the summary table to make the result is readable and understandable. The following table is the summary of regression test conducted:

Table 6. Regression Summary

\begin{tabular}{cccc} 
Variable & $\begin{array}{c}\text { Non- } \\
\text { Standardized } \\
\text { Coefficient }\end{array}$ & T & Sig \\
\hline
\end{tabular}




\begin{tabular}{llrrr}
\hline Equation 1 & (Constant) & $-1,229 \mathrm{E}-16$ & 0,000 & 1,000 \\
& X1 & $-0,196$ & $-2,025$ & $\mathbf{0 , 0 4 5}$ \\
& Sig F Change & 0,045 & & \\
& R Square & 0,038 & & \\
Equation 2 & Adj. R Square & 0,029 & & \\
& (Constant) & $-1,767 \mathrm{E}-16$ & 0,000 & 1,000 \\
& X1 & $-0,196$ & $-2,064$ & $0,042^{*}$ \\
& X2 & $-0,213$ & $-2,244$ & $*$ \\
& Sig F Change & 0,027 & & $\mathbf{0 , 0 2 7} *$ \\
& R. Square & 0,084 & & $*$ \\
Equation 3 & Adj. R Square & 0,066 & & 1,000 \\
& (Constant) & $-2,047 \mathrm{E}-16$ & & $-0,210$ \\
& X1 & $-2,179$ & $0,032^{*}$ \\
& X2 & $-0,234$ & $-2,384$ & $*$ \\
& X1*X2 & 0,078 & 0,856 & $0,019^{*}$ \\
& Sig F Change & 0,394 & & $*$ \\
& R Square & 0,090 & & $\mathbf{0 , 3 9 4} *$ \\
& Adj R. Square & 0,063 & & $*$ \\
& & & & \\
\hline
\end{tabular}

Remarks:

**: $5 \%$ significance(one tail)

$\mathrm{X} 1$ : budget participation

$\mathrm{X} 2$ : outer weights

$\mathrm{X} 1 * \mathrm{X} 2$ : budget participation and outer weights interaction

The first regression analysis was conducted to determine the effect of budgetary participation on the budgetary slack. The regression result of first equation obtained the significance value of 0,045 and it is smaller than the significance value of 0,05 . Therefore, it can be said that budget participation variables affect the budgetary slack.

The results of the first regression equation also generate adjusted R-square of 0.029. It suggests that budget participation variables confirm the variables of the budgetary slack of $2.9 \%$ while the rest are caused by other variables excluding budgetary participation.

The value of $\beta$ in the first equation regression of -0.196 indicates that the correlation between the variable of budget participation with the budgetary slack is negative. This shows the opposite relationship between budgetary participation and budgetary slack. If budgetary participation rises, the budgetary slack will decrease and vice versa if budgetary participation decrease, then the budgetary slack will increase.

The second regression analysis is to include an outer weights variable. This is done to determine whether an outer weight includes a moderation variable or an independent variable.

On second equation of regression, the significance value in ANOVA table is equal to 0,012 which means that variable of budget participation and outer weights influence 
simultaneously to budgetary slack. Meanwhile, the partial significance value between the outer weights to the budgetary slack is 0.027 indicating the outer weights variable affects the budgetary slack. Therefore outer weights are considered as independent variables.

Adjusted R square value of 0.066 indicates budget participation and outer weights which explain the budgetary slack and outer weights by $6.6 \%$, while the rest can be explained by other variables excluding the research variables. By foreseeing at the table of regression in the first equation and second equation, $\mathrm{R}$ square value increased. This indicates that there is an influence of the outer weights on the budgetary slack.

The correlation between the outer weights and the budgetary slack is -0.213 . This value indicates a negative correlation. When external pressure rises, the budgetary slack will decrease and if outer weights decrease, then the budgetary slack decrease.

The third regression equation is to see whether there is moderation between budgetary participation and outer weights on the budgetary slack. The significance value in the 0.022 ANOVA table shows that the budget participation, outer weights and its interaction affect the budgetary slack simultaneously. However, partially, the interaction between budgetary participation and outer weights on the budgetary slack is not significant. It is further confirmed by the significance value of 0.394 . Therefore the outer weights variable is not including the moderating variable affecting the budgetary slack.

The regression summary table describes several regression analysis results starting with the influence of budgetary participation on the budgetary slack (see equation 1). The correlation coefficient is equal to -0.196 with $t$ ( $\mathrm{p}$-value) of -2.025 and a significance level of 0.045 . Therefore, it can be concluded that budget participation has a negative effect on the budgetary slack. Budget participation can predict a budgetary slack of $2.9 \%$.

Hypothesis 2 testing was conducted by using hierarchical regression analysis. This method consists of two fragment model. The first fragment aims at examining the direct influence of budgetary participation and outer weights on the budgetary slack. The second model aims at foreseeing the interaction between budgetary participation and outer weights on the budgetary slack. In accordance with the second model test result (see equation 2) it can be concluded that outer weights are independent variable. This is evident from the significant level ( $p$-value) of less than 0.05 as shown in the table that the value of the outer weights coefficient of 
0.027 correlation coefficient of -0.213 with $\mathrm{t}$ ( $p$-value) of -2.244 . Budget participation and outer weights can predict a budgetary slack amount to $6.6 \%$.

To foresee the moderating effects of outer weights variables, then the third testing model was carried out. The third testing model result demonstrates that outer weights are not a moderating variable. This is seen from the value of B interaction budget participation with the extension of 0.078 with the sig. F of 0.394 . Since the coefficient of outer weights is significant and the interaction coefficient is insignificant, the outer weight is an independent variable instead of moderation variable.

\section{DISCUSSION}

\section{The Influence of Budget Participation on Budgetary Slack}

The first hypothesis (H1) states that budgetary participation negatively affects budgetary slack. The results confirmed that $\mathrm{H} 1$ is proven. This demonstrates that budgetary participation can reduce the occurrence of budgetary slack. The results of this study are consistent with the research conducted by Rahmiati (2013) which states that the higher the participation of officials in the local government in budget preparation, the smaller the tendency of the budgetary slack. Employee participation in the budgeting process will foster higher responsibilities within the employee. This is in accordance with the opinion of Milani (1975) which states that employees will internalize the objectives with a high sense of responsibility since it is involved in the process of budgeting.

To allocate an effective budget, a manager needs a reasonable estimation of the long-run conditions (Nouri and Parker, 1996). Subordinates have more accurate information than authority since they are involving directly during any activity conducted.

Schiff and Lewin (1970) argue that there are some functional aspects of budgetary participation, i.e: (1) Participation will increase subordinates' morale, generate interest, enthusiasm, and initiative. Planning becomes better as a result of the large number of people participating, hence the contribution of their thinking will be beneficial in budgeting. (2) Participation will stimulate cooperation among elements of the company. (3) Direct participation in budgeting makes subordinates understand the goals of the company and they will be more responsive to problems that might arise at the time of implementation. Based on the above arguments and theories, budget participation can decrease budgetary slack. 


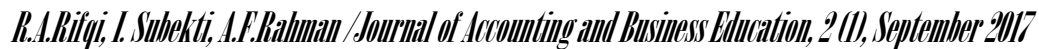

Some scholars argue that budgetary participation has a positive effect on budgetary slack (Young, 1985; Lukka, 1988). One of the performance appraisals is the achievement of budget targets. In order for subordinate's performance is considered as decent, then subordinates ought to accomplish the target budget set by the authority. One of the opportunities that subordinates can take advantage of is when they are asked to participate in budgeting, they will set up an easyto-reach budget by raising spending above their true potential and lowering revenue targets below their true potential.

One of the performance appraisals of civil servants is the achievement of the budget. Officials who draft budgets tend to create easy-to-reach budgets for decent performance. However, recently there is still no performance-related reward and punishment in local government. A well-performing official with a low-performing official receives the same rights, for instance in terms of benefits and honorariums. Therefore, the performance assessment of civil servants in the local government has not been maximized. As a result, during budget allocation an official does not really think about its impact on performance appraisal and budget participation does not positively affect the budgetary slack.

\section{The Influence of Outer Weights on The Budgetary Slack}

The second hypothesis $(\mathrm{H} 2)$ states that the negative effect of budgetary participation on the budgetary slack will be stronger when there are outer weights, meaning that the outer weights variable as a moderating variable that will reinforce the negative effect of budgetary participation on the budgetary slack. However, the results of hypothesis testing prove that outer weight is an independent variable rather than a moderating variable. The results of this study are not supported the second hypothesis.

Institutional pressure tends to develop where performance measurement and control are weak when accountability is low (Frumkin and Galaskiewicz, 2004). This means that low accountability will further strengthen outer weights within a government. In fact, accountability of Probolinggo Municipal Government is low. This can be seen from the Performance Accountability Report of Government Agencies (LAKIP) evaluation which received a C score, in addition Inspection Result Report of State Audit Agency on the financial statements of FY 2015 got "qualified opinion". With the low accountability of the Probolinggo Municipal Government, outer weight is getting stronger and possibly affecting budget formation. 


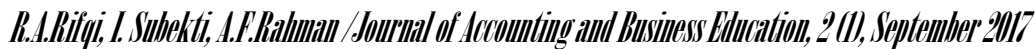

If the political power within the House of Representatives is more dominant, the executive power in negotiating the budget tends to be low. Similar to the budgetary slack, if the House of Representative pressure is very strong, the tendency of officials to do the budgetary slack will be smaller.

The intensity of outer weight felt by executives in particular municipal region will affect the preparation of the budget. The greater the outer weight the more the interests that must be accommodated in the budget. Thereby it minimizes the chances of officials to make budgetary slack. Since outer weight in Probolinggo Municipal Government is high, it is not considered as a moderation that only strengthens or weakens the effect of budgetary participation on budgetary slack. Instead, it performs as a direct influence of budgetary slack.

Another issue that cause high outer weight in the Probolinggo Municipal Government is mass media. The frequent media coverage of corruption cases that dragged some officials of Probolinggo put pressure on officials in Probolinggo Municipal Government. The more frequent news in the mass media will increasingly make the pressure stronger, causing officials more cautious in making decisions, including in preparing the budget.

\section{CONCLUSION}

According to the analysis of results and hypothesis testing, it can be concluded as follows. The higher the budgetary participation, it will reduce the budgetary slack in local government. Contributions in budgeting take place if subordinates are allowed to participate in budgeting activities. Participation in budgeting makes it possible for subordinates to negotiate an opinion with their boss about the budget targets to be achieved thus budgetary slack can be minimized.

This study also proves the influence of outer weight on budget allocation in local government. The influence of external parties in this research is a good influence since it can reduce the occurrence of budgetary slack and maximize the potential of the local government budget.

\section{REFERENCES}


Abdullah, S. (2012). Perilaku Oportunistik Legislatif dan Faktor-Faktor yang Mempengaruhinya: Bukti Empiris dari Penganggaran Pemerintah Daerah di Indonesia. Fakultas Ekonomi dan Bisnis, Universitas Gadjah Mada. Yogyakarta

Abdullah, S. dan Nazri, R. (2015). Analisis Varian Anggaran Pemerintah Daerah. Jurnal Samudra Ekonomi Dan Bisnis, vol.6, no. 2 Juli 2015

Anthony R N. dan Govindarajan, V. (2005). Management System Control. Salemba Empat. Jakarta

Auzair, S. Md dan Smith, K. L. (2004). The effect of service process type, business strategy and life cycle stage on bureaucratic MCS in service organizations. Management Accounting Research 16 (2005) 399-421

Auzair, S. Md. (2010). Organisational Life Cycle Stages and Management Control Systems in Service Organisations. International Jurnal of Business and Management Vol.5, No.111; November 2010

Blanchette, D., Pilote, C. dan Cadieux, J. (2002). Manager's Moral Evaluation of Budgetary Slack Creation.

Brownell, P. (1982). The Role of Accounting Data in Performance Evaluation, Budgetary Participation, and Organizational Effectiveness. Journal of Accounting Research. Vol. 20. No. 1. Pp. 12-27

DiMaggio, P.J dam W.W. Powell. (1983).The Iron Cage Revised: Institutional Isomorphism and Collective Rationality in Organizational Fields. American Sociological Review.

Dunk, A. S. (1993). The Effect of Budget Emphasis and Information Asymmetry on the Relation Between Budgetary Participation and Slack. The Accounting Review, 68, pp. 400-410.

Fisher, J. (1995). Contingency Based Research on Management Control Systems: Categorization By Level Of Complexity. Journal of Accounting Literatur. Vol14. 1995. pp 24-53

Forrester, J. P. (1991). Budgetary Constraints and Municipal Revenue Forecasting.Policy Sciences 24(4): 333-356.

Frumkin, P. dan J. Galaskiewicz. (2004). Institutional Isomorphism and Public Sector Organizations. Journal of Public Administration Research and Theory

Ghozali, I. (2006). Analisis Multivariate dengan Program SPSS. Badan Penerbit Universitas Diponegoro. Semarang. 
Gordon, L.A, dan Miller. (1976). A Contingency Framework for the Design of Accounting Information System. Accounting. Organization and Society.

Govindarajan, V. (1986). Impact of Participation in The Budgetary Process on Managerial Attitudes and Performance: Universalistic and Contingency Perspectives. Decision Sciences. Vol. 17. Pp. 496-516.

Hansen, D. R dan Mowen,M.M. (2006). Management Accounting. Salemba Empat. Jakarta

Julnes, P. de L dan Holzer, M. (2001). Promoting the Utilization of Performance Measures in Public Organization: an Empirical Study of Factors Affecting Adoption and Implementation.Public Administration Review, 61(6), 693-708

Lukka, K. (1988). Budgetary Beasing in organization: Theoretical Framework and Empirical Evidence. Accounting, Organization and Society. pp: 281-301.

Mardiasmo. (2002). Otonomi dan Manajemen Keuangan Daerah. Andi. Yogyakarta.

Merchant, K. A. (1985). Budgeting and the Propensity to Create Budgetarily Slack. Accounting, Organization and Society, 10, pp. 201-210.

Meyer, J. dan B. Rowan. (1977). Institutionalized Organizations Formal Structure as Myth and Ceremony. The American Journal of Sociology.

Milani, K. 1975. The Relationship of Participation in Budget-Setting to Industrial Supervisor Performance and Attitude: A Field Study, The Accounting Review.pp: 274-284.

Mizruchi, M. S. dan L. C. Fein. (1999). The Social Construction of Organizational Knowledge A Study of the Uses of Coercive, Mimetic, and Normative Isomorphism. Administrative Science Quarterly

Norton, A\&Elson, D. (2002). What's Behind the Budget? Politics, Rights and Accountability in the Budget Process. Working Paper. Overseas Development Institute.

Otley, D. T. (1980). The Contingency Of management Accounting: Achievement and Prognosis. Accounting, Organization and Society, Oxford.pp.412-428.

Othman, R dan Haryanti Binti Mohd Noor, Ida. (2012). Budgetary Participation: How It Affects Performance And Commitment. Accountancy Business and the Public Interest

Rahim, Syamsuri. (2013). Pengaruh Ethical Judgment dan Moral Reasoning Terhadap Slack Anggaran Dengan Variabel Intervening Partisipasi Anggaran dan Komitmen Organisasi. Disertasi. Universitas Brawajaya. Malang. 
Rahmiati, Elfi. (2013). Pengaruh Partisipasi Anggaran Terhadap Senjangan Anggaran Dengan Asimetri Informasi Dan Komitmen OrganisasiSebagai Pemoderasi (Studi Empiris Pada Pemerintah Daerah Kota Padang).Skripsi. Univeristas negeri padang.

Schiff, M dan A. Y. Lewin. (1970).The Impact of Budgets on people. The Accounting Review Vol. 45. pp: 259-268.

Scott, W. R. (2008). Institutions And Organizations: Ideas and interests, 3rd ed. Thousand Oaks, CA: Sage

Syahrir, A. D. (2016). Pengaruh Penganggaran Partisipatif Terhadap Budget Slack Dengan Sikap Sebagai Variabel Moderating.Tesis. Universitas Brawijaya. Malang

Von Hagen, J. (2002). Fiscal Rules, Fiscal Institutions, and Fiscal Performance. The Economic and Social review 33(3): 263-284.

Wang, X. (2002). Assessing Performance Measurement Impact: A study of US Local Government. Public Performance and Management Review, 26, 26-43.

Young, S. M. (1985). Participative Budgeting: The Effects of Risk Aversion and Asymmetric Information on Budgetary Slack. Journal of Accounting Research, Vol. 23, No. 2. (Autumn), pp. 829-842.

\section{Attachment}

KMO Test and Bartlett's Independent Variable Test KMO and Bartlett's Test

Kaiser-Meyer-Olkin Measure of Sampling Adequacy.

Bartlett's Test of Sphericity Approx. Chi-Square

\section{KMO Test and Bartlett's Dependent Variable Test}

\section{KMO and Bartlett's Test}

Kaiser-Meyer-Olkin Measure of Sampling Adequacy.

Bartlett's Test of Sphericity

\begin{tabular}{lr} 
Approx. Chi-Square & 173.712 \\
df & 21 \\
Sig. & .000 \\
\hline
\end{tabular}




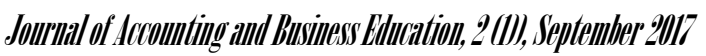

\begin{tabular}{|c|c|c|c|c|c|c|c|c|c|c|c|c|c|c|c|c|}
\hline & & PA_1 & PA_2 & PA_3 & PA_4 & PA_5 & PA_6R & TE_1 & TE_2 & TE_3 & TE_4 & TE_5 & TE_6 & TE_7 & TE_8 & TE_9 \\
\hline \multirow{15}{*}{ Anti-image Covariance } & PA_1 & .499 & -.132 & -.103 & -.005 & -.045 & -.123 & -.047 & .037 & -.007 & -.007 & .020 & -.022 & -.033 & -.110 & .042 \\
\hline & PA_2 & -.132 & .491 & -.135 & -.149 & -.059 & .029 & .020 & -.116 & .064 & .010 & .028 & -.115 & .048 & -.096 & .015 \\
\hline & PA_3 & -.103 & -.135 & .485 & -.080 & -.017 & -.067 & .038 & .058 & -.009 & -.072 & .075 & .057 & -.063 & .101 & -.151 \\
\hline & PA_4 & -.005 & -.149 & -.080 & .535 & -.145 & -.072 & .117 & .020 & -.087 & .059 & -.091 & .068 & .000 & -.025 & .064 \\
\hline & PA_5 & -.045 & -.059 & -.017 & -.145 & .546 & -.047 & -.142 & .077 & .051 & .077 & -.086 & .040 & -.068 & -.013 & -.083 \\
\hline & PA_6R & -.123 & .029 & -.067 & -.072 & -.047 & .525 & -.136 & .102 & .045 & -.028 & .027 & -.023 & -.123 & .006 & -.082 \\
\hline & TE_1 & -.047 & .020 & .038 & .117 & -.142 & -.136 & .686 & -.058 & -.210 & -.015 & -.016 & -.146 & .119 & .024 & .018 \\
\hline & TE_2 & .037 & -.116 & .058 & .020 & .077 & .102 & -.058 & .492 & -.213 & -.093 & -.048 & .041 & -.096 & -.019 & -.017 \\
\hline & TE_3 & -.007 & .064 & -.009 & -.087 & .051 & .045 & -.210 & -.213 & .642 & .000 & .021 & -.054 & -.006 & -.022 & -.089 \\
\hline & TE_4 & -.007 & .010 & -.072 & .059 & .077 & -.028 & -.015 & -.093 & .000 & .374 & -.260 & .006 & -.044 & .087 & .099 \\
\hline & TE_5 & .020 & .028 & .075 & -.091 & -.086 & .027 & -.016 & -.048 & .021 & -.260 & .369 & -.016 & .062 & -.117 & -.110 \\
\hline & TE_6 & -.022 & -.115 & .057 & .068 & .040 & -.023 & -.146 & .041 & -.054 & .006 & -.016 & .749 & -.250 & .037 & .039 \\
\hline & TE_7 & -.033 & .048 & -.063 & .000 & -.068 & -.123 & .119 & -.096 & -.006 & -.044 & .062 & -.250 & .638 & -.147 & -.072 \\
\hline & TE_8 & -.110 & -.096 & .101 & -.025 & -.013 & .006 & .024 & -.019 & -.022 & .087 & -.117 & .037 & -.147 & .765 & .069 \\
\hline & TE_9 & .042 & .015 & -.151 & .064 & -.083 & -.082 & .018 & -.017 & -.089 & .099 & -.110 & .039 & -.072 & .069 & .788 \\
\hline \multirow[t]{15}{*}{ Anti-image Correlation } & PA_1 & $.868^{\mathrm{a}}$ & $\begin{array}{l}-.266 \\
\end{array}$ & $\begin{array}{l}-209 \\
\end{array}$ & -.010 & -.085 & -.240 & -.080 & .074 & -.012 & -.017 & .048 & -.036 & -.058 & -.177 & .066 \\
\hline & PA_2 & -.266 & $.772^{\mathrm{a}}$ & -.276 & -.290 & -.114 & .057 & .034 & -.236 & .113 & .023 & .065 & -.190 & .086 & -.157 & .024 \\
\hline & PA_3 & -.209 & -.276 & $.805^{a}$ & -.157 & -.033 & -.134 & .066 & .119 & -.017 & -.170 & .176 & .095 & -.114 & .166 & -.245 \\
\hline & PA_4 & -.010 & -.290 & -.157 & $.775^{a}$ & -.269 & -.136 & .193 & .039 & -.149 & .132 & -.204 & .107 & -.001 & -.039 & .099 \\
\hline & PA_5 & -.085 & -.114 & -.033 & -.269 & $.818^{a}$ & -.089 & -.232 & .149 & .085 & .170 & -.191 & .063 & -.116 & -.020 & -.127 \\
\hline & PA_6R & -.240 & .057 & -.134 & -.136 & -.089 & $.835^{\mathrm{a}}$ & -.227 & .201 & .077 & -.064 & .062 & -.036 & -.212 & .010 & -.127 \\
\hline & TE_1 & -.080 & .034 & .066 & .193 & -.232 & -.227 & $.511^{\mathrm{a}}$ & -.099 & -.316 & -.030 & -.033 & -.203 & .180 & .033 & .025 \\
\hline & TE_2 & .074 & -.236 & .119 & .039 & .149 & .201 & -.099 & $.727^{\mathrm{a}}$ & -.379 & -.216 & -.113 & .068 & $\begin{array}{l}-.172 \\
-\end{array}$ & -.030 & -.028 \\
\hline & TE_3 & -.012 & .113 & -.017 & -.149 & .085 & .077 & -.316 & -.379 & $.642^{\mathrm{a}}$ & -.001 & .043 & -.078 & -.010 & -.031 & -.125 \\
\hline & TE_4 & -.017 & .023 & -.170 & .132 & .170 & -.064 & -.030 & -.216 & -.001 & $.588^{a}$ & -.700 & .012 & -.090 & .163 & .182 \\
\hline & TE_5 & .048 & .065 & .176 & -.204 & -.191 & .062 & -.033 & -.113 & .043 & -.700 & $.548^{a}$ & -.030 & .128 & -.220 & -.203 \\
\hline & TE_6 & -.036 & -190 & .095 & .107 & .063 & -.036 & -.203 & .068 & -.078 & .012 & -.030 & $.582^{\mathrm{a}}$ & -.362 & .049 & .050 \\
\hline & TE_7 & -.058 & .086 & -.114 & -.001 & -.116 & -.212 & .180 & -.172 & -.010 & -.090 & .128 & -.362 & $.684^{a}$ & -.211 & -.101 \\
\hline & TE_8 & -.177 & -.157 & .166 & -.039 & -.020 & .010 & .033 & -.030 & -.031 & .163 & -.220 & .049 & -.211 & $.627^{a}$ & .089 \\
\hline & TE_9 & .066 & .024 & -.245 & .099 & -.127 & -.127 & .025 & -.028 & -.125 & .182 & -.203 & .050 & -.101 & .089 & $.622^{\mathrm{a}}$ \\
\hline
\end{tabular}

